\title{
Research Square \\ Expression of cardiac copper chaperone encoding genes and their correlation with cardiac function parameters in goats
}

Ahmed S. Mandour ( $\nabla$ dr_mandour@vet.suez.edu.eg )

Suez Canal University Faculty of Veterinary Medicine https://orcid.org/0000-0001-6256-4539

Ahmed E. Mahmoud

Suez Canal University Faculty of Veterinary Medicine

Asmaa 0. Ali

Suez Canal University Faculty of Veterinary Medicine

Katsuhiro Matsuura

Tokyo Noko Daigaku

Haney Samir

Cairo University Faculty of Veterinary Medicine

Hend A. Abdelmageed

Animal Health Research Institute

Danfu Ma

Tokyo Noko Daigaku

Tomohiko Yoshida

Tokyo Noko Daigaku

Lina Hamabe

Tokyo Noko Daigaku

Akiko Uemura

Obihiro Chikusan Daigaku

Gen Watanabe

Tokyo Noko Daigaku

Ryou Tanaka

Tokyo Noko Daigaku

\section{Research Article}

Keywords: Copper deficiency, goats, echocardiography, mRNA expression, copper chaperone, trace elements

Posted Date: April 29th, 2021 
DOl: https://doi.org/10.21203/rs.3.rs-457799/v1

License: (c) (1) This work is licensed under a Creative Commons Attribution 4.0 International License. Read Full License

Version of Record: A version of this preprint was published at Veterinary Research Communications on July 6th, 2021. See the published version at https://doi.org/10.1007/s11259-021-09811-5. 


\section{Abstract}

The expression of copper chaperone (Cu-Ch) encoding genes enables an in-depth understanding of copper-associated disorders, but no previous studies have been undertaken to highlight $\mathrm{Cu}-\mathrm{Ch}$ disturbances in heart tissue in ruminants after copper deficiency (CuD). The current study aimed to investigate the Cu-Ch mRNA expression in goat's heart after experimental CuD and highlight their relationship with the cardiac measurements. Eleven male goats were enrolled and divided into the control group $(n=4)$ and CuD group (treatment, $n=7)$, which received copper-reducing dietary regimes (molybdenum and sulfur). Heart function was evaluated by electrocardiography and echocardiography, and at the end of the experiment, all animals were sacrificed, and the cardiac tissues were collected for quantitative mRNA expression by real-time PCR. In the treatment group, cardiac measurements revealed increased preload and the existence of cardiac dilatation and significant cardiac tissue damage by histopathology. Also, the relative mRNA expression of Cu-Ch encoding genes; ATP7A, CTr1, LOX, COX17, as well as ceruloplasmin (CP), troponin 13 (TNNI3), glutathione peroxidase (GPX1), and matrix metalloprotease inhibitor (MMPI1) genes were significantly down-regulated in CuD group. Besides, there was a variable significant correlation between investigated genes and cardiac measurements; meanwhile, a significant inverse correlation was observed between histopathological score and ATP7B, CTr1, LOX, and $C O X 17$. In conclusion, this study revealed that CuD induces cardiac dilatation and alters the mRNA expression of $\mathrm{Cu}-\mathrm{Ch}$ genes, in addition to TNNI3, GPX1, and MMPI1 that are considered key factors in clinically undetectable CuD-induced cardiac damage in goats which necessitate further studies for feasibility as biomarkers.

\section{Introduction}

Copper $(\mathrm{Cu})$ is known to have exciting and crucial importance for various physiological processes because of being an essential cofactor for numerous enzymatic activities. These activities including, but not limited to, iron metabolism, erythropoiesis, energy production, collagen formation, hormone biosynthesis, and antioxidant defense against peroxidative damage (Sinclair and Mackenzie 2013). The safety margin of dietary $\mathrm{Cu}$ in farm animals is comparatively narrow, and the dietary deficiency due to antagonistic elements such as sulfur and molybdenum, and over-supplementation due to hepatic loading makes ensuring Cu adequacy a nutritional challenge (López-Alonso and Miranda 2020).

In the biological systems, $\mathrm{Cu}$ has unique electrochemical properties which shift between two independent valence states, the reduced monovalent and the oxidized divalent. Copper homeostasis within the cell is regulated by a distinctive transport and traffic system known as metallochaperones or copper chaperone proteins (Cu-Ch), which helps in delivering Cu to the target site without inflicting harm or becoming impound in unplanned sites. These chaperones include $\mathrm{Cu}$ transporter protein (CTr1), ATPases 7 alpha and beta $(A T P 7 A, A T P 7 B)$, chaperone for superoxide dismutase (CCS), cytochrome c oxidase 17 (COX17), and lysyl oxidase $(\angle O X)$. These chaperones help to regulate $\mathrm{Cu}$ uptake, export, and intracellular compartmentalization, and much of these chaperones have been learned from studies on isolated proteins, knockout or mutant mice, and cell culture systems. The expression of genes encoding these 
proteins is guarded by certain transcriptional regulators known as metalloregulatory proteins (Fry et al. 2013, Prohaska and Gybina 2004, Reyes-Caballero et al. 2011).

The requirement of $\mathrm{Cu}$ in cardiac muscles is comparatively high to maintain the high energy requirement which is necessary for continuous muscle contraction, antioxidant, and other critical functions (Kim et al. 2010, Medeiros et al. 1993). Therefore, Cu exserts a potent cardiovascular health relevance because of its incorporation as a cofactor in antioxidant superoxide dismutase, lysyl oxidase, and mitochondrial cytochrome c-oxidase (Fukai et al. 2018). Studies revealed that Cu deficiency (CuD) could be a leading cause of adverse cardiac events including ischemic and hypertrophic disorders (DiNicolantonio et al. 2018, Li et al. 2018, Liu et al. 2018). Also, the alteration in the myocardial Cu acquisition mechanism was recently pointed out as the key factor in diabetes-induced heart failure in rats (Zhang et al. 2020). Thus, during heart failure, the low level of left ventricular Cu concentration could aggravate the development of cardiac dysfunction due to extensive changes in myofibrillar and mitochondrial morphology and distribution (Zhang et al. 2014).

Ruminants have a well-adapted mechanism to accommodate dietary Cu restriction via reducing its biliary excretion. This mechanism is important to alleviate the effect of hypocuprosis; however, these animals become more vulnerable to hepatic overloading when excess $\mathrm{Cu}$ is available, particularly in cattle and sheep (Suttle 2012). On the contrary, goats are more tolerant to higher dietary Cu concentrations than sheep without any signs of Cu toxicity (Huang et al. 2013) owing to lower hepatic Cu uptake (Solaiman et al. 2001, Zervas et al. 1990), but this also notoriously increases the goat's susceptibility to clinical hypocuprosis (Ivan et al. 1990, Silva et al. 2014). Despite clinical studies focusing on cardiac damage in ruminants due to $\mathrm{CuD}$ is limited, cardiac ultrastructural and biochemical alterations in calves (Olivares et al. 2019), as well as disturbances in heart measurements during CuD in goats (Mandour et al. 2021), have been recently studied.

Simultaneous usage of clinical investigation based on molecular changes is aroused in cardiovascular diseases to establish diagnostic biomarkers. Currently, data are available on the characterization of $\mathrm{Cu}$ metabolism and homeostasis in mice (Lee et al. 2000), humans (Lee et al. 2002), and cattle (Hepburn et al. 2009). However, little is known about the selective genetic basis of Cu chaperones in the ruminant's heart. To our knowledge, there is no study exploring the relationship between cardiac measurements and the expression of $\mathrm{Cu}$ chaperone encoding genes in any of farm animals. Therefore, the current experiment aimed to investigate the changes in Cu-Ch mRNA expression in CuD-induced cardiac damage and highlight the relationship between the expression level and cardiac measurements as well as the histopathological scoring in goats.

\section{Materials And Methods}

\section{Animals and experimental design}

The experimental procedures were followed by the recommendations of the Animal Experimental Committee held in the Tokyo University of Agriculture and Technology, Japan (approval No. 29-5). Eleven 
male Shiba goats, 2-3 years old and weight $45 \pm 5 \mathrm{~kg}$ were included and showed all signs of soundness based on the examination criteria of goats (Radostits et al. 2000). All animals received alfalfa hay cubes (Edinburg, USA) as a base diet twice a day to meet the nutritional needs for maintenance (NRC 2007) which provides $11.0,0.5$, and $0.5 \mathrm{mg} / \mathrm{kg}$ of $\mathrm{Cu}$, molybdenum, and sulfur respectively throughout the experiment. The dietary analysis is provided as a supplementary table (1). After one month of dietary adaptation, goats were divided into two groups; the control group ( $n=4$ goats) which received the normal diet, and the treatment group $(n=7)$ in which Cu-reducing compounds; ammonium sulfate and sodium molybdate, were added to the diet for 7 months (Mandour et al. 2021). CuD was confirmed clinically by the appearance of deteriorative changes of skin and coat, and laboratory by reduced plasma $\mathrm{Cu}$ concentration, ceruloplasmin, superoxide dismutase, as well as other biochemical parameters (supplementary Table 2). During the experiment, the cardiac function was evaluated by electrocardiography and echocardiography (Mandour et al. 2021).

\section{Assessment of cardiac functions}

The electrocardiography (ECG) from the base apex lead was carried out using Cardisuny (Cardisuny, M-E 8000 BP, Fukuda, Japan). The ECG-derived data included wave durations measured as milliseconds (ms), voltage expressed as millivolt (mv), as well as cardiac intervals (PR, RR, ST, QT) derived from the standard ECG waves (P, QRS, and T) measured as ms (Koether et al. 2016). In standing position, right side two-dimensional and short-axis M-mode echocardiography at the level of the papillary muscles were performed using the ultrasound machine (EUB-7500, Hitachi Medical Corporation, Tokyo, Japan) equipped with a sector probe (3-7 MHz; Model EUP-L65; Hitachi Medical Corporation, Tokyo, Japan) (Mandour et al. 2020b). A detailed description of the preparation and recording procedures was previously described (Mandour et al. 2021). The measured cardiac function parameters include interventricular septum diameters in diastole and systole (IVSd, IVSs), left ventricular free wall diameters in diastole and systole (LVPWd, LVPWs), left ventricular internal-diastolic diameter and volume (LVIDd, EDV), left ventricular internal-systolic diameter and volume (LVIDs, ESV), stroke volume (SV), cardiac output (CO), right ventricular internal-diastolic diameter (RVIDd), left ventricular ejection fraction (EF), left ventricular fractional shortening (FS), aortic root diameter (Ao), left atrium diameter in late systole (LADs), left atrial diameter:Aortic diameter ratio (LA/Ao), and pulmonary artery diameter (PA). The mean of the measured parameters was obtained from 5 repeated heart cycles. The ECG and echocardiography were done twice before euthanasia and the data were averaged.

\section{Euthanasia, sample collection, and histopathology}

At the end of the experiment, all goats were euthanized using a combination of xylazine $(0.05 \mathrm{mg} / \mathrm{Kg} \mathrm{BW}$, xylazine hydrochloride, Fujita-Pharm, Japan), and $30 \mathrm{mg} / \mathrm{kg}$ pentobarbital (pentobarbital, Somuno Pentil injection ${ }^{\circledR}$, Kyoritsu Seiyaku Corporation, Tokyo, Japan). For histopathology, formalin-preserved specimens were dehydrated by ethanol and xylene, blocked in paraffin wax, sectioned at $4 \mu \mathrm{m}$, and then underwent H\&E staining. A semi-quantitative histopathologic scoring was carried out blindly (Suvarna et 
al. 2018). Tissue specimens from different parts of the heart were collected, washed with molecular water, and properly kept at $-80 \mathrm{C}^{\circ}$ for further analysis.

\section{Analysis of cardiac tissue trace elements}

Cardiac tissue samples from each animal were collected, finely chopped, dried overnight at $100 \mathrm{C}^{\circ}$ in a hot air oven, finely grounded by mortar and pestle, and $100 \mathrm{mg}$ of the mixture was digested with concentrated nitric acid (Suzuki et al. 2007). After filtration, the resultant solution was diluted with molecular water and analyzed by ICP-MS using the previously mentioned procedures (Mandour et al. 2020a). ICP-MS setting condition was illustrated in the supplementary table (3).

\section{Quantitative mRNA expression}

Cardiac tissue samples were finely minced, and $0.1 \mathrm{mg}$ of the tissues were used for the total RNA extraction by Isogen II reagent (Nippon gene co, Itd) according to the manufacturer's instructions. The RNA was normalized at $300 \mathrm{ng} / \mathrm{ul}$ using Tris EDTA (TE). Complementary cDNA was created using PrimeScript $1^{\text {st }}$ cDNA kit (Takara Bio Inc., Otsu, Japan). The mRNA expression of five Cu chaperone encoding genes (CTr1, LOX1, COX17, CCS, ATP7A, ATP7B), antioxidant encoding genes (glutathione peroxidase, GPX1; superoxide dismutase 1, SOD1), ceruloplasmin $(C P)$, matrix metalloproteinase inhibitor 1 (MMPI1) for cardiac damage, and cardiac troponin I3 (TNNI3) for myocardial protein marker were examined. The oligonucleotide primers were designed using web-based Primer3 software (http://primer3.wi.m 119 it.edu/). Details of the target genes and sequences of the used primers are shown in Table (1). Conventional PCR and agarose gel electrophoresis were carried out to identify the expression specificity of the target mRNA with the used primer sequences. For real-time PCR, the PCR reactions were carried out in a $10 \mu$ l volume using Ex TaqR Hot Start version containing SYBR-Green I (Takara, Kusatsu, Shiga, Japan ) with a real-time PCR system (Applied biosystem, Foster City, CA) using the following conditions: $95 \mathrm{C}^{\bullet}$ for 30 seconds; followed by 40 cycles of $95 \mathrm{C}^{\bullet}$ for 5 seconds, $60 \mathrm{C} \bullet$ for 30 seconds and then a dissociation protocol. The relative expression level of each target mRNA was calculated using the $2-{ }^{\Delta \Delta} \mathrm{CT}$ method in which all values were normalized to the housekeeping gene $\beta$ actin.

\section{Statistical analysis}

The normality test of the obtained data was assessed using the Kolmogorov-Smirnov (KS) test. All data were analyzed by unpaired t-test for parametric data with a probability of $P<0.05$, and the data are expressed as Mean \pm SEM using Graphpad prism 6 (GraphPad Software, San Diego, CA, USA). Multiple Person's correlation analysis was done between the relative mRNA expressions in the cardiac tissue and element concentration $(\mathrm{Cu}, \mathrm{Mo})$, cardiac parameters, and histopathological scoring.

\section{Results}


Table 2 summarizes the changes in the cardiac dimension obtained from ECG and right side echocardiography in both groups. The results revealed a significant reduction in P-wave time $(P=0.004)$ as well as T-wave time and T-wave voltage ( $P=0.021$, and 0.042 , respectively) in the treatment group compared with the control. On the contrary, QRS-wave time $(P=0.023)$, ST-segment $(P=0.040)$, calculated QT $(P=0.041)$, diastolic left ventricle (LV) internal diameter $(P=0.027)$, LV end-diastolic volume $(P=0.004)$, stroke volume $(P=0.030)$, cardiac output $(P=0.040)$, diastolic right ventricular internal diameter $(P=0.021)$, diastolic left atrial (LA) diameter $(P=0.048)$, and the LA area $(P=0.027)$ were significantly increased in the treatment group in comparison to the control.

\section{Quantitative mRNA expression of encoding genes in the cardiac tissues}

Figure (1) illustrates mRNAs expression of cardiac Cu-Ch encoding genes. The result revealed that the relative expressions of $A T P 7 A, A T P 7 B, C T r 1, \angle O X$, and $C O X 17$ were significantly down-regulated in the cardiac tissue of the treatment group compared with the control $(P=0.0049,0.044,0.023,0.049$, and 0.029 , respectively); meanwhile, $C C S$ showed no significant change $(P=0.750)$.

Figure 2 summarizes the results of $S O D 1, C P, G P X 1, M M P 1$, and $T N N / 3$ mRNA expressions in the heart. The data showed that $C P, G P X 1, M M P I 1$, and $T N N B$ expressions were significantly reduced $(P=0.016$, $0.001,0.002$, and 0.031 , respectively) in the treatment group compared with the control, whilst SOD1 was reduced but not statistically significant $(P=0.111)$.

\section{Effect of cardiac copper and molybdenum concentrations on the investigated mRNA expressions}

In the treatment group, the level of cardiac tissue $\mathrm{Cu}$, iron $(\mathrm{Fe})$, were significantly reduced compared with the control group $(P<0.05)$, meanwhile, Mo concentration was significantly increased $(P<0.01)$ (supplementary table 4). Pearson's correlation between cardiac $\mathrm{Cu}$ and Mo concentrations and the mRNA expression level of the targeted genes are summerized in Table (3). The obtained results revealed no significant correlation between cardiac $\mathrm{Cu}$ concentration and encoding gene expressions $(P>0.05)$.

\section{Relationship between mRNA expression and cardiac measurements}

\section{a.Correlation with ECG parameters}

Table (4.A) illustrates the correlation between ECG parameters and mRNA expression in cardiac tissues. $S O D 1$ showed a significantly strong negative correlation with $\mathrm{P}$-wave time $(\mathrm{r}=-0.83, P=0.042)$. Besides, GPX1 showed a significantly strong negative correlation with ST-segment $(\mathrm{r}=-0.86, P=0.036)$. Cardiac $C P$ and COX17 were strongly and positively correlated with both T-wave time $(\mathrm{r}=0.82,0.87 ; P<0.05)$ and Twave voltage $(\mathrm{r}=0.90,0.83 ; P<0.05)$, respectively; meanwhile, the TNNI3 showed a significant strong positive correlation with T-wave duration $(r=0.86, P=0.032)$.

\section{b.Correlation with echocardiographic measurements}


Table (4.B) summarizes the relationship between mRNA encoding gene expressions and echocardiographic measurements. The left atrial diameter (LADs) showed a significant strong negative correlation with $C \operatorname{Tr} 1(r=-0.23, P=0.031), \operatorname{COX17}(r=-0.85, P=0.037), C P(r=-0.95, P=0.001), M M P I 1(r=-0.89$, $P=0.023)$ and $T N N I 3(r=-0.83 ; P=0.046)$, respectively. Similarly, the CP, ATP7B, CTr1, LOX, COX17, MMPI1, and $T N N / 3$ showed significant strong inverse correlation with LA/Ao ratio $(r=-0.86,-0.87,-0.95,-0.84$, $-0.83,-0.93,-0.81 ; P=0.033,0.021,0.005,0.041,0.043,0.015$, and 0.044 , respectively). Also, significant strong positive correlation between $\mathrm{EF}$ and $\operatorname{ATB} 7 B(r=0.87, P=0.022)$ as well as between EF and $\angle O X$ expression ( $r=0.88, P=0.024)$ were reported. Also, the RVIDd showed a significant strong positive correlation with $C \operatorname{Tr} 1(r=-0.84, P=0.041)$. ATP7A showed an inverse correlation with LVIDd, LVIDs, EDV, and ESV.

\section{c.Correlation with the histopathological score}

In the treatment group, cardiac tissue damage was detected as myocardial degeneration, focal cardiac necrosis, leukocytic infiltrations, and atrophied muscles (Figure 3). The overall score of cardiac damage in the treatment group was significantly higher than the control group $(2.78 \pm 0.32$ and $0.8 \pm 0.2$ respectively; $P=0.011)$. There was significant negative correlation between histopathological score and mRNA expression of $A T P 7 B(\mathrm{r}=-0.735, P=0.038), C \operatorname{Tr} 1(\mathrm{r}=-0.765, P=0.027), \operatorname{LOX}(\mathrm{r}=-0.744, P=0.034)$, $\operatorname{COX17}(\mathrm{r}=-0.829, P=0.11)$, and TNN13 ( $\mathrm{r}=-0.756, P=0.030)$, while MMP/1 was trend $(\mathrm{r}=-0.688, P=0.059)$. CCS, ATP7A, SOD, CP, and GPX showed no significant correlation with the histopathological score.

\section{Discussion}

Copper deficiency is a grave nutritional disorder not only because it is widely spread but also due to its secondary multi-organ disorders. The problem constitutes a nutritional challenge in grazing ruminants particularly, but not limited to, tropical regions where the soil is deficient in $\mathrm{Cu}$ or excessive $\mathrm{Cu}$ antagonisms are found with high levels (López-Alonso and Miranda 2020). In the current study, we conducted a dietary $\mathrm{Cu}$ restriction protocol to reduce $\mathrm{Cu}$ availability by creating a chemical reaction between sulfur and molybdenum in the ruminal fluid (Gould and Kendall 2011, Scheiber et al. 2013). We aimed to highlight, for the first time, the disruption in Cu-Ch mRNA expression in cardiac tissues in Shiba goats, a native Japanese non-seasonal breeding breed that is considered to be a good model for studying the cardiac blood flow and ruminant animal physiology (Mandour et al. 2020a, Samir et al. 2020), to find out whether $\mathrm{Cu}$ deficiency is correlated with cardiac measurements and histopathological scoring.

In the current work, the ECG has been evaluated from the base apex lead only. This is a common and suitable lead to investigate arrhythmias in farm animals since it provides easily detectable waves and minimizes movement-related erroneous measurements (Fakour et al. 2013, Mousavi et al. 2007, Radostits et al. 2006, Rezakhani et al. 2004). Besides, the echocardiography has been evaluated only from the right side and without Doppler evaluation of the flow tracts because of the difficulty to obtain Doppler alignment in the standing position. This has been previously attributed to the presence of gases- 
filled rumen (Leroux et al. 2012) in addition to the large-sized goats included in this study compared with goats used in our previous report (Mandour et al. 2020b).

In our previous study, we investigated the longitudinal disruption of cardiac measurements in experimentally-induced CuD in goats throughout different time intervals (Mandour et al. 2021); however, in this study, we measured the cardiac parameters after confirming CuD-associated cardiac involvement to correlate the data with Cu-Ch mRNA expressions. The treatment group showed dilated LV which was indicated by increased QRS time, LV internal diameter in diastole, LV end-diastolic volume, stroke volume, and cardiac output, in addition to increased left atrium size. These changes have been attributed to increasing preload, which induced cardiac remodeling as dilatation to accommodate the increased blood volume (Turner et al. 2002, Yamaya et al. 1997). The nonsignificant decline in EF and FS indicated that the CuD-associated cardiac damage was not severe enough to induce cardiomyopathy and systolic dysfunction in goats. This finding enforces the silent change in cardiac function in goats that could tolerate the adverse effect of CuD without cardiovascular symptoms. In contrast, dramatic cardiac tissue damage in copper-deficient goats was detected that could be explained by the increased oxidative damage secondary to a reduction in Cu level that in turn leads to lower $S O D, C P$, and $G P X$ expression (McDowell 2003, Olivares et al. 2019). Copper is known to comprise copious cardiovascular-relevant functions to withstand the high-energy demand necessary for maintaining continuous heart contractility. Therefore, in CuD, there is a deprivation of $\mathrm{Cu}$ and improper activity of Cu-dependent metalloenzymes, which further influence collagen cross-linkage, energy production, and antioxidant defense mechanism (Smith 2014, Vázquez-Armijo et al. 2011).

Copper homeostasis within the cell is mediated by $\mathrm{Cu}$-Ch proteins to ensure adequate $\mathrm{Cu}$ absorption and intracellular distribution (Fry et al. 2013, Prohaska and Gybina 2004). Our results showed significant down-regulation in the relative expression of $C P, A T P 7 A, C T r 1, \angle O X$, and $C O X 17$ in cardiac tissues of the treatment group compared with the control; meanwhile, SOD1, CCS, and ATP7B were not significantly reduced. There is a shortage of data in ruminants regarding the effect of $\mathrm{CuD}$ on cardiac $\mathrm{Cu}$ regulation genes. Nevertheless, our results were consistent with previously reported data in other species (Dermauw et al. 2014, Getz et al. 2011, Han et al. 2009, Han et al. 2012, Hepburn et al. 2009). Simmental cattle, a highly susceptible breed to CuD, showed reduced mRNA expression of COX17, CTr1, and ATP7A in duodenal tissue, placenta, and liver compared with the non-deficient breed (Fry 2011, Fry et al. 2013). Also, hepatic Cu-regulating genes in Cu-deficient cross-breed cattle were less than the non-deficient Zebu cattle (Dermauw et al. 2014). Furthermore, Cardiac COX1 and COX4 proteins were down-regulated in Cudeficient rats (Getz et al. 2011). Despite the above-mentioned studies were focused on cattle and rats, their data indicate that $\mathrm{CuD}$ down-regulates the Cu-regulating genes in duodenal and hepatic tissues. Thereafter, the same effect could exist in the goat's heart.

Rather than Cu-Ch mRNA encoding genes, in the present study, the GPX1, MMPI1, and TNNI3 mRNA expressions were significantly reduced in cardiac tissues of Cu-deficient goats. Experimental CuD in cattle reduces hepatic GPX1 in which selenium level is also reduced (Dermauw et al. 2014). Histopathologically, we demonstrated that CuD resulted in cardiac tissue damage and fibrosis. This could be explained by the 
combination of reduced $\mathrm{Cu}$ concentration, together with reduced SOD1, CP, and GPX expression in the cardiac tissues. For further illustration, Gunja-Smith et al. (1996) suggested that the down-regulation of MMPI1 could inhibit the activity of metalloproteases and subsequent accumulation of weak cross-linked collagen fibers and cardiac dilatation [45]. The cross-linkage of the collagen is the function of the Cudependent enzyme lysyl oxidase (López et al. 2010), which is regulated by LOX chaperone that was reduced in the current study. Therefore, it can be stated that down-regulation of LOX and MMPI1 in CuD aggravates cardiac tissue damage by deposition of abnormal extracellular matrix, and the result will be expressed clinically as increased preload and dilatation. Furthermore, $T N N / 3$, a gene encoding cardiac sarcomere troponin I protein, was examined as a regulating gene for cardiac proteins necessary for proper assembly of the cardiomyocytes. Changes in $T N N / 3$ are a well-known cause of cardiomyopathy (Mirza et al. 2005, Rai et al. 2009) and its expression showed down-regulation in cardiac muscles of type2 diabetes (Howarth et al. 2011) in which Cu plays an important role in its development due to defective myocellular Cu regulation (Zhang et al. 2014, Zhang et al. 2020).

The correlation between $\mathrm{Cu}$ concentration and the investigated genes in the cardiac tissues revealed no significant correlation. A variable correlation between pulmonary artery Cu concentration and mRNA expression of Cu regulating genes was also observed in goats, cattle, and pigs (Dermauw et al. 2014, Han et al. 2012) in which the authors suggested that these genes are regulated differently among species.

To the best of our knowledge, this is the first study to demonstrate the correlation between Cu-regulating genes as well as CP, SOD1, GPX1, TNNI3, and MMPI1 in the cardiac tissue and cardiac parameters in goats. Even though our findings indicated variable correlations with heart function measurements, the observed significant correlation of certain mRNA encoding gene expression and specific cardiac measurements enforced our observation of impacted cardiac functions under CuD due to disturbances at the molecular level. This finding was further confirmed by the significant negative correlation with the histopathological score. However, further studies with different levels of $\mathrm{Cu}$ status and response to copper supplement is warranted to prove the direct link between copper chaperone encoding gene expression and cardiac dysfunction caused by CuD in ruminants.

\section{Conclusion}

In this study, CuD significantly down-regulated the cardiac tissue mRNA expressions of copper chaperones in addition to SOD1, CP, GPX1, MMPI1, and TNNI3 and some of them were negatively correlated with the degree of cardiac tissue damage. Disturbances at the molecular level in CuD aggravate heart tissue damage and induce tissue remodeling in goats regardless of no clear symptoms of cardiovascular events were detected. The usefulness of $\mathrm{Cu}$ chaperones as biomarkers in clinically undetectable CuD-related heart damage in ruminants warranted further studies.

\section{References}


Dermauw V, De Cuyper A, Duchateau L, Waseyehon A, Dierenfeld E, Clauss M, Peters IR, Du Laing G, Janssens GPJ (2014) A disparate trace element metabolism in zebu (Bos indicus) and crossbred (Bos indicus $\times$ Bos taurus) cattle in response to a copper-deficient diet1. J Anim Sci. 92:3007-3017. $10.2527 /$ jas.2013-6979

DiNicolantonio JJ, Mangan D, O'Keefe JH (2018) Copper deficiency may be a leading cause of ischaemic heart disease. Open Heart. 5:e000784. https://doi.org/10.1136/openhrt-2018-000784

Fakour S, Mokhber Dezfuli M, Nadalian M, Rezakhani A, Lotfollah Zadeh S (2013) Electrocardiographic parameters of Markhoz goat using base apex lead and six standard limb leads. Iran J Vet Res. 14:241244.

Fry RS (2011) Dietary and Genetic Effects on Cellular Copper Homeostasis in Bovine and Porcine Tissues. Ph.D Thesis, North Carolina State University, ProQuest Dissertations Publishing

Fry RS, Spears JW, Lloyd KE, O'Nan AT, Ashwell MS (2013) Effect of dietary copper and breed on gene products involved in copper acquisition, distribution, and use in Angus and Simmental cows and fetuses. J Anim Sci. 91:861-871. https://doi.org/10.2527/jas.2011-3888

Fukai T, Ushio-Fukai M, Kaplan JH (2018) Copper transporters and copper chaperones: roles in cardiovascular physiology and disease. Am J Physiol Cell Physiol. 315:C186-c201.

10.1152/ajpcell.00132.2018

Getz J, Lin D, Medeiros DM (2011) The Cardiac Copper Chaperone Proteins Sco1 and CCS are UpRegulated, but Cox 1 and Cox4 are Down-Regulated, by Copper Deficiency. Biol Trace Elem Res. 143:368377. https://doi.org/10.1007/s12011-010-8858-z

Gould L, Kendall NR (2011) Role of the rumen in copper and thiomolybdate absorption. Nutr Res Rev. 24:176-182. https://doi.org/10.1017/S0954422411000059

Gunja-Smith Z, Morales AR, Romanelli R, Woessner JF, Jr. (1996) Remodeling of human myocardial collagen in idiopathic dilated cardiomyopathy. Role of metalloproteinases and pyridinoline cross-links. Am J Pathol. 148:1639-1648.

Han H, Archibeque SL, Engle TE (2009) Characterization and Identification of Hepatic mRNA Related to Copper Metabolism and Homeostasis in Cattle. Biol Trace Elem Res. 129:130-136. 10.1007/s12011-0088293-6

Han H, So H, Domby E, Engle T (2012) The relationship of pulmonary artery copper concentrations and genes involved in copper homeostasis in cattle, Swine, and goats. Asian-Australas J Anim Sci. 25:194199. https://doi.org/10.5713/ajas.2011.11196

Hepburn JJ, Arthington JD, Hansen SL, Spears JW, Knutson MD (2009) Technical note: copper chaperone for copper, zinc superoxide dismutase: a potential biomarker for copper status in cattle. J Anim Sci. 
Howarth FC, Qureshi MA, Hassan Z, Al Kury LT, Isaev D, Parekh K, Yammahi SRKD, Oz M, Adrian TE, Adeghate $\mathrm{E}$ (2011) Changing pattern of gene expression is associated with ventricular myocyte dysfunction and altered mechanisms of Ca2+ signalling in young type 2 Zucker diabetic fatty rat heart. Exp Physiol. 96:325-337. https://doi.org/10.1113/expphysiol.2010.055574

Huang YL, Wang Y, Spears JW, Lin X, Guo CH (2013) Effect of copper on performance, carcass characteristics, and muscle fatty acid composition of meat goat kids. J Anim Sci. 91:5004-5010. https://doi.org/10.2527/jas.2012-5820

Ivan M, Hidiroglou M, Al-Ismaily SI, Al-Sumry HS, Harper RB (1990) Copper deficiency and posterior paralysis (shalal) in small ruminants in the sultanate of oman. Trop Anim Health Prod. 22:217-225. 10.1007/BF02240402

Kim BE, Turski ML, Nose Y, Casad M, Rockman HA, Thiele DJ (2010) Cardiac copper deficiency activates a systemic signaling mechanism that communicates with the copper acquisition and storage organs. Cell Metab. 11:353-363. https://doi.org/10.1016/j.cmet.2010.04.003

Koether K, Ulian CM, Lourenco ML, Goncalves RS, Sudano MJ, Cruz RK, da Silva Branchini N, Alfonso A, Chiacchio SB (2016) The normal electrocardiograms in the conscious newborn lambs in neonatal period and its progression. BMC Physiol. 16:1. https://doi.org/10.1186/s12899-016-0020-5

Lee J, Prohaska JR, Dagenais SL, Glover TW, Thiele DJ (2000) Isolation of a murine copper transporter gene, tissue specific expression and functional complementation of a yeast copper transport mutant. Gene. 254:87-96.

Lee J, Pena MM, Nose Y, Thiele DJ (2002) Biochemical characterization of the human copper transporter Ctr1. J Biol Chem. 277:4380-4387. https://doi.org/10.1074/jbc.M104728200

Leroux AA, Moonen ML, Farnir F, Sandersen CF, Deleuze S, Salciccia A, Amory H (2012) Two-dimensional and M-mode echocardiographic reference values in healthy adult Saanen goats. Vet Rec. 170:154-154. https://doi.org/10.1136/vr.100192

Li K, Li C, Xiao Y, Wang T, James Kang Y (2018) Featured Article: The loss of copper is associated with the increase in copper metabolism MURR domain 1 in ischemic hearts of mice. Exp Biol Med. 243:780785. https://doi.org/10.1177/1535370218773055

Liu J, Chen C, Liu Y, Sun X, Ding X, Qiu L, Han P, James Kang Y (2018) Feature Article: Trientine selectively delivers copper to the heart and suppresses pressure overload-induced cardiac hypertrophy in rats. Exp Biol Med. 243:1141-1152. https://doi.org/10.1177/1535370218813988

López-Alonso M, Miranda M (2020) Copper Supplementation, A Challenge in Cattle. Animals (Basel). https://doi.org/1010.3390/ani10101890 
López B, González A, Hermida N, Valencia F, Teresa Ed, Díez J (2010) Role of lysyl oxidase in myocardial fibrosis: from basic science to clinical aspects. Am J Physiol Heart Circ Physiol. 299:H1-H9. https://doi.org/10.1152/ajpheart.00335.2010

Mandour AS, Samir H, El-Beltagy MA, Abdel-Daim MM, Izumi W, Ma D, Matsuura K, Tanaka R, Watanabe G (2020a) Effect of supra-nutritional selenium-enriched probiotics on hematobiochemical, hormonal, and Doppler hemodynamic changes in male goats. Environ Sci Pollut Res. 27:19447-19460. https://doi.org/10.1007/s11356-020-08294-2

Mandour AS, Samir H, Yoshida T, Matsuura K, Abdelmageed HA, Elbadawy M, Al-Rejaie S, El-Husseiny HM, Elfadadny A, Ma D, Takahashi K, Watanabe G, Tanaka R (2020b) Assessment of the Cardiac Functions Using Full Conventional Echocardiography with Tissue Doppler Imaging before and after Xylazine Sedation in Male Shiba Goats. Animals. 10:2320. https://doi.org/10.3390/ani10122320

Mandour AS, Elsayed RF, Ali AO, Mahmoud AE, Samir H, Dessouki AA, Matsuura K, Watanabe I, Sasaki K, Al-Rejaie S, Yoshida T, Shimada K, Tanaka R, Watanabe G (2021) The utility of electrocardiography and echocardiography in copper deficiency-induced cardiac damage in goats. Environ Sci Pollut Res. 28:78157827. https://doi.org/10.1007/s11356-020-11014-5

McDowell LR (2003): Minerals in animal and human nutrition. Elsevier Science BV

Medeiros DM, Davidson J, Jenkins JE (1993) A unified perspective on copper deficiency and cardiomyopathy. Proc Soc Exp Biol Med. 203:262-273. https://doi.org/10.3181/00379727-203-43599

Mirza M, Marston S, Willott R, Ashley C, Mogensen J, McKenna W, Robinson P, Redwood C, Watkins H (2005) Dilated Cardiomyopathy Mutations in Three Thin Filament Regulatory Proteins Result in a Common Functional Phenotype. J Biol Chem. 280:28498-28506.

https://doi.org/10.1074/jbc.M412281200

Mousavi G, Hassanpour A, Tabrizi A, Rezaie A (2007) Electrocardiographic changes in buffaloes with Traumatic reticuloperitonitis. Italian J Anim Sci. 6:1029-1031. https://doi.org/10.4081/ijas.2007.s2.1029

NRC (2007) Nutrient requirements of small ruminants: sheep, goats, cervids, and New World camelids. National Research Council of the National Academies, National Academies Press, Washington, D.C., U.S.A.

Olivares RWI, Postma GC, Schapira A, Iglesias DE, Valdez LB, Breininger E, Gazzaneo PD, Minatel L (2019) Biochemical and Morphological Alterations in Hearts of Copper-Deficient Bovines. Biol Trace Elem Res. 189:447-455. https://doi.org/10.1007/s12011-018-1476-x

Prohaska JR, Gybina AA (2004) Intracellular copper transport in mammals. J Nutr. 134:1003-1006. https://doi.org/10.1093/jn/134.5.1003 
Radostits OM, Mayhew IG, Houston DM (2000): Veterinary clinical examination and diagnosis. WB Saunders

Radostits OM, Gay CC, Hinchcliff KW, Constable PD (2006): Veterinary Medicine E-Book: A textbook of the diseases of cattle, horses, sheep, pigs and goats. Elsevier Health Sciences

Rai TS, Ahmad S, Ahluwalia TS, Ahuja M, Bahl A, Saikia UN, Singh B, Talwar KK, Khullar M (2009) Genetic and clinical profile of Indian patients of idiopathic restrictive cardiomyopathy with and without hypertrophy. Mol Cell Biochem. 331:187. https://doi.org/10.1007/s11010-009-0157-7

Reyes-Caballero H, Campanello GC, Giedroc DP (2011) Metalloregulatory proteins: metal selectivity and allosteric switching. Biophys Chem. 156:103-114. https://doi.org/10.1016/j.bpc.2011.03.010

Rezakhani A, Paphan AA, Shekarfroush S (2004) Analysis of base apex lead electrocardiograms of normal dairy cows. Veterinarski arhiv. 74:351-358.

Samir H, Nyametease P, Elbadawy M, Fathi M, Mandour AS, Radwan F, Nagaoka K, Sasaki K, Watanabe G (2020) Assessment of correlations and concentrations of salivary and plasma steroids, testicular morphometry, and semen quality in different climatic conditions in goats. Theriogenology. 157:238-244. https://doi.org/10.1016/j.theriogenology.2020.08.002

Scheiber I, Dringen R, Mercer JF (2013) Copper: effects of deficiency and overload, Interrelations between essential metal ions and human diseases. Springer, pp. 359-387

Silva T, Aguiar G, Carvalho F, Simões S, Neto EM, Dantas A, Soares P, Riet-Correa F (2014) Outbreaks of copper deficiency in ruminants in the semiarid region of Paraíba, Brazil. Semina: Ciências Agrárias. 35:1955-1960.

Sinclair L, Mackenzie A (2013) Mineral nutrition of dairy cows: supply vs. requirements. Recent Advances in Animal Nutrition:13-30.

Smith BP (2014): Large animal internal medicine-E-Book. Elsevier Health Sciences

Solaiman SG, Maloney MA, Qureshi MA, Davis G, D'Andrea G (2001) Effects of high copper supplements on performance, health, plasma copper and enzymes in goats. Small Ruminant Res. 41:127-139. https://doi.org/10.1016/S0921-4488(01)00213-9

Suttle NF (2012) Copper imbalances in ruminants and humans: unexpected common ground. Adv Nutr. 3:666-674. https://doi.org/10.3945/an.112.002220

Suvarna KS, Layton C, Bancroft JD (2018): Bancroft's theory and practice of histological techniques EBook. Elsevier Health Sciences 
Suzuki Y, Watanabe I, Oshida T, Chen YJ, Lin LK, Wang YH, Yang KC, Kuno K (2007) Accumulation of trace elements used in semiconductor industry in Formosan squirrel, as a bio-indicator of their exposure, living in Taiwan. Chemosphere. 68:1270-1279. https://doi.org/10.1016/j.chemosphere.2007.01.053

Turner LR, Premo DA, Gibbs BJ, Hearthway ML, Motsko M, Sappington A, Walker L, Mullendore ME, Chew HG, Jr. (2002) Adaptations to iron deficiency: cardiac functional responsiveness to norepinephrine, arterial remodeling, and the effect of beta-blockade on cardiac hypertrophy. BMC Physiol. 2:1. https://doi.org/10.1186/1472-6793-2-1

Vázquez-Armijo J, Rojo R, López D, Tinoco J, González A, Pescador N, Domínguez-Vara I (2011) Trace elements in sheep and goats reproduction: A review. Trop Subtrop Agroecosyst. 14:1-13.

Yamaya Y, Kubo K, Amada A (1997) Relationship between Atrio-Ventricular Conduction and Hemodynamics during Atrial Pacing in Horses. J Equine Sci. 8:35-38. https://doi.org/10.1294/jes.8.35

Zervas G, Nikolaou E, Mantzios A (1990) Comparative study of chronic copper poisoning in lambs and young goats. Anim Sci. 50:497-506. https://doi.org/10.1017/S0003356100004980

Zhang S, Liu H, Amarsingh GV, Cheung CC, Hogl S, Narayanan U, Zhang L, McHarg S, Xu J, Gong D, Kennedy J, Barry B, Choong YS, Phillips AR, Cooper GJ (2014) Diabetic cardiomyopathy is associated with defective myocellular copper regulation and both defects are rectified by divalent copper chelation. Cardiovasc Diabetol. 13:100. https://doi.org/10.1186/1475-2840-13-100

Zhang S, Liu H, Amarsingh GV, Cheung CCH, Wu D, Narayanan U, Zhang L, Cooper GJS (2020) Restoration of myocellular copper-trafficking proteins and mitochondrial copper enzymes repairs cardiac function in rats with diabetes-evoked heart failure. Metallomics. 12:259-272. https://doi.org/10.1039/c9mt00223e

\section{Tables}




\begin{tabular}{|c|c|c|}
\hline Target mRNA & Direction & Sequence \\
\hline Copper transporter protein 1 (CTr1) & $\begin{array}{l}\text { Forward } \\
\text { Reverse }\end{array}$ & $\begin{array}{l}\text { ggagggcgacaaatgtgtactt } \\
\text { caaqgogttgqaatqagagaaa }\end{array}$ \\
\hline Lysyl oxidase (LOX1) & Forward & caaccgtcttctgatccagtga \\
\hline Cytochrome oxidase 17 (COX17) & $\begin{array}{l}\text { Reverse } \\
\text { Forward } \\
\text { Reverse }\end{array}$ & $\begin{array}{l}\text { ttgaaaaataggagggcacagg } \\
\text { tgcgtgcataattgagaaagga } \\
\text { tattcactcccagaocagacca }\end{array}$ \\
\hline Copper chaperone for SOD1 (CCS) & Forward & ctccagtctgtcaccgtcct \\
\hline ATPase 7 alpha (ATP7A) & $\begin{array}{l}\text { Forward } \\
\text { Reverse }\end{array}$ & $\begin{array}{l}\text { gtttgctggaccgaattgtt } \\
\text { caacgcactgtcgtcatctt }\end{array}$ \\
\hline ATPase 7 beta $(A T P 7 B)$ & $\begin{array}{l}\text { Forward } \\
\text { Reverse }\end{array}$ & $\begin{array}{l}\text { cttatccaaccccaagacctca } \\
\text { tctatgqgtcccagqcttactg }\end{array}$ \\
\hline Superoxide dismutase (SOD1) & $\begin{array}{l}\text { Forward } \\
\text { Reverse }\end{array}$ & $\begin{array}{l}\text { atggattccacgtccatcagtt } \\
\text { tttttgtcagccttcacattgc }\end{array}$ \\
\hline Ceruloplasmin $(C P)$ & $\begin{array}{l}\text { Forward } \\
\text { Reverse }\end{array}$ & $\begin{array}{l}\text { ctcaatggtgtggtgtcagg } \\
\text { tctgagctgtagqgottgt }\end{array}$ \\
\hline Matrix metalloproteinase inhibitor 1 (MMPI1) & $\begin{array}{l}\text { Forward } \\
\text { Reverse }\end{array}$ & $\begin{array}{l}\text { gatgaggtccggtttttcaa } \\
\text { aggagcctggcagactacaa }\end{array}$ \\
\hline Glutathione peroxidase 1 (GPX1) & $\begin{array}{l}\text { Forward } \\
\text { Reverse }\end{array}$ & $\begin{array}{l}\text { ctgcggcattcacgaaacta } \\
\text { atgccagggtacatggtggt }\end{array}$ \\
\hline Cardiac troponin I3 (TNNI3) & $\begin{array}{l}\text { Forward } \\
\text { Reverse }\end{array}$ & $\begin{array}{l}\text { cctcaagcaggtgaagaagg } \\
\text { caqctcagccctcaaacttc }\end{array}$ \\
\hline$\beta$-actin & $\begin{array}{l}\text { Forward } \\
\text { Reverse }\end{array}$ & $\begin{array}{l}\text { ctgcggcattcacgaaacta } \\
\text { atgccagggtacatggtggt }\end{array}$ \\
\hline
\end{tabular}

Table 1 Oligonucleotide primer sequence for real-time PCR

Table 2 Measurement of cardiac dimensions in control and copper-deficient goats 


\begin{tabular}{|c|c|c|c|c|}
\hline Groups & Unit & $\begin{array}{l}\text { Control } \\
(\mathrm{n}=4)\end{array}$ & $\begin{array}{l}\text { Treatment } \\
(\mathrm{n}=7)\end{array}$ & $p$-value \\
\hline $\mathrm{P}$ time & $\mathrm{ms}$ & $52.90^{* *} \pm 5.5$ & $36.60 \pm 2.4$ & $0.004^{* *}$ \\
\hline QRS time & $\mathrm{ms}$ & $58.11 \pm 0.7$ & $78.66^{*} \pm 5.4$ & $0.023^{*}$ \\
\hline $\mathrm{T}$ time & ms & $83.50^{*} \pm 6.7$ & $59.75 \pm 6.1$ & $0.021^{*}$ \\
\hline$P$ voltage & $\mathrm{mv}$ & $0.19 \pm 0.0$ & $0.16 \pm 0.0$ & 0.368 \\
\hline QRS voltage & $\mathrm{mv}$ & $0.42 \pm 0.0$ & $0.55 \pm 0.2$ & 0.428 \\
\hline $\mathrm{T}$ voltage & $\mathrm{mv}$ & $0.43^{*} \pm 0.1$ & $0.29 \pm 0.1$ & 0.042 \\
\hline RR interval & $\mathrm{ms}$ & $670.5 \pm 60.9$ & $644.5 \pm 41.3$ & 0.568 \\
\hline ST segment & $\mathrm{ms}$ & $146.1 \pm 9.1$ & $199.5^{*} \pm 8.6$ & $0.040^{*}$ \\
\hline PR interval & $\mathrm{ms}$ & $87.17 \pm 2.6$ & $90.33 \pm 8.8$ & 0.666 \\
\hline QT interval & $\mathrm{ms}$ & $310.7 \pm 12.5$ & $335.0 \pm 25.9$ & 0.041 \\
\hline Calculated QT & ms & $225.8 \pm 12.5$ & $315.4^{*} \pm 23.0$ & 0.561 \\
\hline IVSd & $\mathrm{cm}$ & $0.91 \pm 0.1$ & $1.01 \pm 0.1$ & 0.636 \\
\hline LVIDd & $\mathrm{cm}$ & $4.03 \pm 0.0$ & $4.85^{*} \pm 0.5$ & $0.027^{*}$ \\
\hline LVFWd & $\mathrm{cm}$ & $1.01 \pm 0.1$ & $1.22 \pm 0.2$ & 0.332 \\
\hline EDV & $\mathrm{ml}$ & $73.7 \pm 6.6$ & $120.2^{* *} \pm 10.7$ & $0.004^{* *}$ \\
\hline IVSs & $\mathrm{cm}$ & $1.32 \pm 0.2$ & $1.47 \pm 0.1$ & 0.642 \\
\hline LVIDs & $\mathrm{cm}$ & $1.99 \pm 0.1$ & $2.38 \pm 0.2$ & 0.217 \\
\hline LVFWs & $\mathrm{cm}$ & $1.92 \pm 0.2$ & $2.28 \pm 0.3$ & 0.278 \\
\hline ESV & $\mathrm{ml}$ & $13.45 \pm 1.1$ & $20.49 \pm 1.5$ & 0.229 \\
\hline $\mathrm{HR}$ & bpm & $90.0 \pm 6.0$ & $98.0 \pm 5.0$ & 0.542 \\
\hline SV & $\mathrm{ml}$ & $71.89 \pm 1.9$ & $79.23^{* *} \pm 5.3$ & $0.030^{*}$ \\
\hline $\mathrm{CO}$ & $\mathrm{L} / \mathrm{min}$ & $5.22 \pm 0.5$ & $8.20^{*} \pm 0.7$ & $0.040^{*}$ \\
\hline FS & $\%$ & $50.7 \pm 2.6$ & $42.5 \pm 1.5$ & 0.795 \\
\hline $\mathrm{EF}$ & $\%$ & $84.4 \pm 2.3$ & $65.3 \pm 1.5$ & 0.128 \\
\hline RVIDd & $\mathrm{cm}$ & $1.33 \pm 0.1$ & $1.88^{*} \pm 0.2$ & 0.021 \\
\hline AoDd & $\mathrm{cm}$ & $2.34 \pm 0.1$ & $2.48 \pm 0.1$ & 0.808 \\
\hline LADs & $\mathrm{cm}$ & $3.25 \pm 0.2$ & $3.79^{*} \pm 0.1$ & 0.048 \\
\hline LA/Ao & & $1.38 \pm 0.1$ & $1.57 \pm 0.2$ & 0.121 \\
\hline LAAs & $\mathrm{cm}$ & $13.50 \pm 0.6$ & $16.90^{*} \pm 0.3$ & $0.027^{*}$ \\
\hline $\mathrm{PA}$ & $\mathrm{cm}$ & $1.71 \pm 0.1$ & $1.80 \pm 0.1$ & 0.421 \\
\hline
\end{tabular}

Note: Data are tested using unpaired T-test, and values are presented as mean \pm SEM. ${ }^{*} P<0.05$. IVSd, interventricular septum diameter in diastole; LVIDd, left ventricular (LV) internal diameter in diastolic; LVFWd, LV free wall diameter in diastole; IVSs, interventricular septum diameter in systolic; LVIDs, LV internal diameter in systolic; LVFWs, LV free wall diameter in systole; EDV, end-diastolic volume of LV; ESV, end-systolic volume of LV; EF, ejection fraction; FS, fraction shortening; LADs, left atrial diameter in systole; AoDd, aortic diameter in diastole; LA/Ao, the ratio between left atrium to aortic diameters; LAAs, left atrial area in systole; PA, pulmonary artery diameter.

Table 3 Correlation between heart copper and molybdenum concentration and encoding gene expressions 


\begin{tabular}{lllll}
\hline \multirow{2}{*}{ Target gene } & $\mathrm{Cu}$ & \multicolumn{3}{l}{$\mathrm{Mo}$} \\
\cline { 2 - 5 } & $\mathrm{r}$ & $P$ & $\mathrm{r}$ & $p$-value \\
\hline CCS & -0.018 & 0.967 & -0.099 & 0.815 \\
ATP7A & 0.563 & 0.146 & -0.131 & 0.755 \\
ATP7B & 0.182 & 0.665 & -0.287 & 0.489 \\
CTr1 & 0.132 & 0.756 & -0.336 & 0.415 \\
LOX & 0.038 & 0.929 & -0.224 & 0.593 \\
COX17 & 0.202 & 0.632 & -0.252 & 0.546 \\
SOD1 & 0.109 & 0.798 & 0.103 & 0.807 \\
CP & 0.453 & 0.260 & -0.606 & 0.111 \\
GPX1 & 0.047 & 0.912 & -0.305 & 0.462 \\
MPI1 & -0.008 & 0.985 & -0.506 & 0.200 \\
TNNI3 & 0.634 & 0.092 & -0.409 & 0.313
\end{tabular}

r; Pearson's correlation between elements concentration (Cu, copper; Mo, Molybdenum) and mRNA expression of examined genes in cardiac tissue in Shiba goats $(P<0.05)$.

Table 4 Correlation between cardiac mRNA expression of encoding genes and heart function parameters

\begin{tabular}{|c|c|c|c|c|c|c|c|c|c|c|c|}
\hline $\begin{array}{l}\text { Measured } \\
\text { parameters }\end{array}$ & CCS & ATP7A & ATP7B & CTr1 & LOX & COX17 & SOD1 & $\overline{\mathrm{CP}}$ & GPX1 & MMPI1 & TNNI3 \\
\hline \multicolumn{12}{|l|}{ A.ECG } \\
\hline P time $(\mathrm{ms})$ & 0.82 & -0.54 & -0.25 & -0.21 & -0.31 & 0.23 & $-0.83 *$ & -0.14 & -0.36 & -0.18 & 0.26 \\
\hline QRS time (ms) & -0.55 & -0.51 & -0.27 & -0.35 & -0.26 & -0.69 & 0.26 & -0.65 & -0.47 & -0.37 & -0.7 \\
\hline $\mathrm{T}$ time $(\mathrm{ms})$ & 0.59 & 0.25 & 0.81 & 0.81 & 0.77 & $0.87 *$ & 0.19 & $0.82 *$ & 0.58 & 0.76 & $0.86 *$ \\
\hline $\mathrm{P}$ voltage (mv) & 0.12 & -0.30 & -0.36 & -0.17 & -0.43 & -0.11 & -0.54 & -0.26 & -0.35 & -0.11 & -0.04 \\
\hline QRS voltage (mv) & -0.11 & 0.31 & 0.10 & -0.09 & 0.18 & -0.05 & 0.26 & 0.12 & 0.35 & -0.16 & -0.12 \\
\hline $\mathrm{T}$ voltage $(\mathrm{mv})$ & 0.33 & 0.64 & 0.79 & 0.73 & 0.81 & $0.83^{*}$ & 0.47 & $0.90^{*}$ & 0.71 & 0.72 & 0.79 \\
\hline RR interval (ms) & -0.37 & -0.66 & -0.53 & -0.47 & -0.56 & -0.67 & -0.17 & -0.76 & -0.71 & -0.43 & -0.63 \\
\hline ST segment (ms) & -0.23 & -0.73 & -0.53 & -0.57 & -0.54 & -0.62 & -0.12 & -0.79 & $-0.86^{*}$ & -0.52 & -0.6 \\
\hline PR interval (ms) & -0.54 & 0.37 & -0.31 & -0.19 & -0.3 & -0.23 & 0.11 & -0.13 & -0.14 & -0.07 & -0.22 \\
\hline QT interval (ms) & -0.5 & 0.14 & 0.06 & -0.12 & 0.13 & -0.33 & 0.56 & -0.13 & 0.09 & -0.16 & -0.39 \\
\hline $\begin{array}{ll}\text { Calculated } & \text { QT } \\
(\mathrm{ms}) & \\
\end{array}$ & -0.18 & 0.58 & 0.62 & 0.53 & 0.64 & 0.44 & 0.76 & 0.58 & 0.42 & 0.57 & 0.39 \\
\hline \multicolumn{12}{|c|}{ B.Echocardiography } \\
\hline IVSd (cm) & -0.77 & 0.22 & 0.05 & -0.02 & 0.11 & -0.52 & 0.52 & -0.14 & -0.16 & -0.57 & -0.57 \\
\hline LVIDd (cm) & -0.11 & -0.78 & -0.18 & -0.19 & -0.22 & -0.42 & -0.02 & -0.56 & -0.59 & -0.20 & -0.39 \\
\hline LVPWd (cm) & 0.19 & -0.79 & -0.17 & -0.19 & -0.21 & -0.3 & -0.33 & -0.46 & -0.26 & -0.27 & -0.27 \\
\hline EDV (ml) & -0.14 & -0.75 & -0.14 & -0.16 & -0.18 & -0.42 & 0.02 & -0.53 & -0.54 & -0.18 & -0.39 \\
\hline IVSs (cm) & $-0.98 * *$ & 0.19 & -0.23 & -0.19 & -0.19 & -0.66 & 0.44 & -0.35 & -0.21 & -0.67 & -0.67 \\
\hline LVIDs (cm) & -0.2 & -0.79 & -0.5 & -0.47 & -0.54 & -0.62 & -0.25 & -0.77 & -0.76 & -0.44 & -0.57 \\
\hline LVFWs (cm) & 0.12 & -0.81 & -0.27 & -0.32 & -0.31 & -0.43 & -0.32 & -0.57 & -0.39 & -0.4 & -0.4 \\
\hline ESV (ml) & -0.22 & -0.78 & -0.43 & -0.41 & -0.47 & -0.59 & -0.18 & -0.73 & -0.72 & -0.39 & -0.55 \\
\hline HR (bpm) & -0.17 & 0.71 & 0.6 & 0.62 & 0.62 & 0.56 & 0.68 & 0.69 & 0.45 & 0.71 & 0.53 \\
\hline $\mathrm{SV}(\mathrm{ml})$ & -0.12 & -0.73 & -0.07 & -0.12 & -0.11 & -0.37 & 0.07 & -0.48 & -0.49 & -0.13 & -0.35 \\
\hline $\mathrm{CO}(\mathrm{L} / \mathrm{min})$ & -0.16 & -0.68 & 0.01 & -0.03 & -0.04 & -0.32 & 0.17 & -0.42 & -0.46 & -0.05 & -0.3 \\
\hline FS \% & -0.67 & -0.41 & -0.25 & -0.26 & -0.25 & -0.68 & 0.3 & -0.59 & -0.40 & -0.27 & -0.67 \\
\hline $\mathrm{EF} \%$ & 0.32 & 0.26 & $0.87^{*}$ & 0.75 & $0.88 *$ & 0.65 & 0.57 & 0.71 & 0.61 & 0.66 & 0.6 \\
\hline RVIDd (cm) & 0.34 & 0.02 & 0.81 & $0.84^{*}$ & 0.76 & 0.68 & 0.41 & 0.62 & 0.35 & 0.81 & 0.69 \\
\hline AoD (cm) & 0.22 & -0.49 & 0.21 & 0.23 & 0.16 & 0.04 & -0.06 & -0.05 & 0.15 & 0.07 & 0.07 \\
\hline LADs (cm) & -0.13 & -0.76 & -0.79 & $-0.86^{*}$ & -0.74 & $-0.85^{*}$ & -0.53 & $-0.95^{* *}$ & -0.89 & $-0.83^{*}$ & $-0.83^{*}$ \\
\hline LA:Ao & -0.28 & -0.41 & -0.87 & -0.95 & -0.84 & -0.83 & -0.45 & -0.86 & -0.93 & -0.81 & -0.81 \\
\hline LAA s & -0.22 & -0.12 & 0.0 & 0.08 & -0.02 & 0.02 & 0.29 & -0.11 & 0.23 & 0.04 & -0.26 \\
\hline $\mathrm{PA}(\mathrm{cm})$ & 0.62 & -0.56 & 0.23 & 0.19 & 0.18 & 0.41 & -0.03 & 0.04 & 0.29 & 0.44 & 0.44 \\
\hline
\end{tabular}


Figures

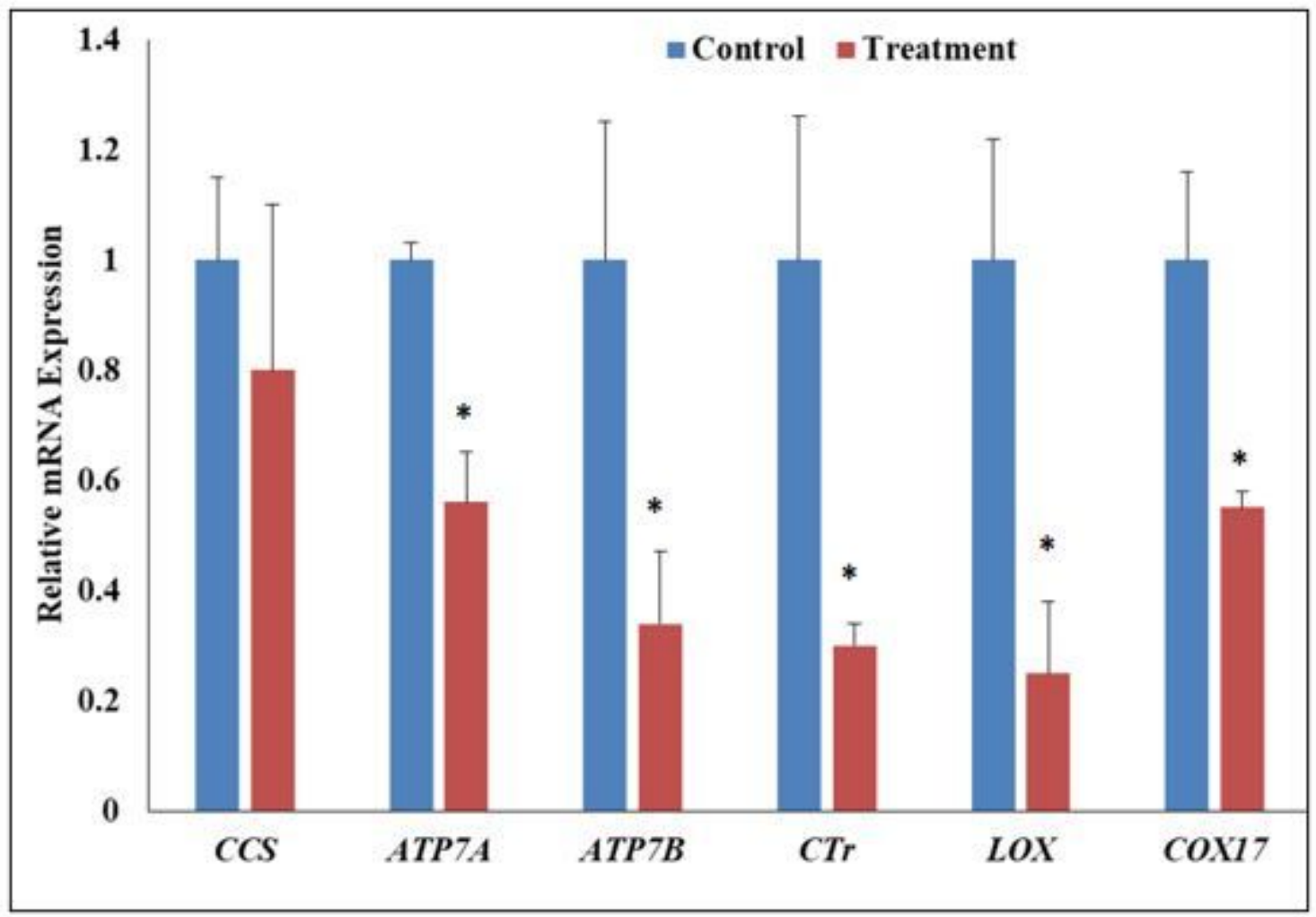

Figure 1

mRNA Expression level (Mean \pm SEM) of copper chaperone encoding genes in the cardiac tissues in the control and copper-deficient goats. The data revealed down-regulation of copper regulating genes in the cardiac tissues of deficient goats. ${ }^{*} P<0.05$. 


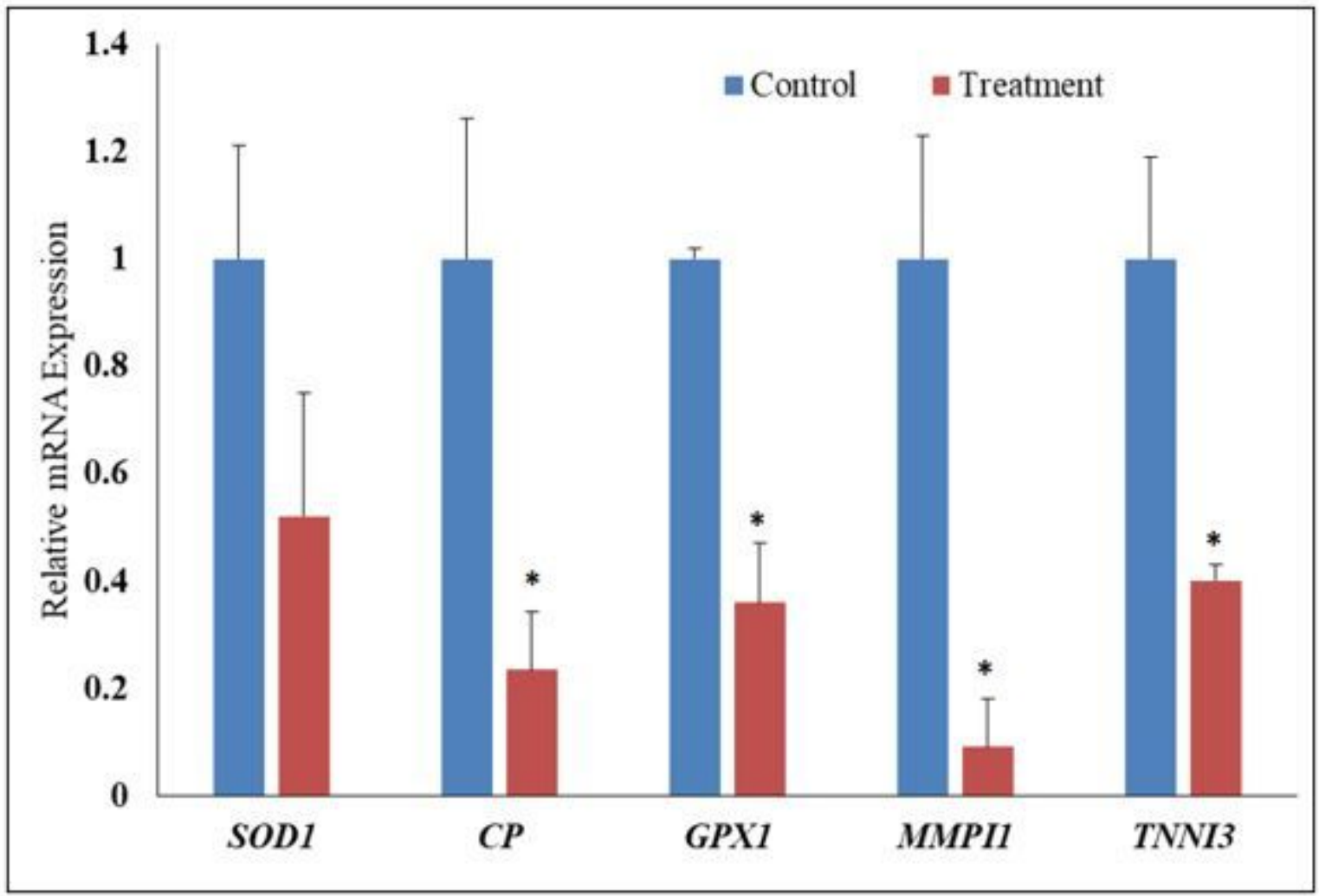

Figure 2

mRNA Expression level (Mean \pm SEM) of SOD1, CP, GPX1, MMPI1, and TNNI3 in the cardiac tissues in the control and copper-deficient (treatment) goats. The results showed a reduction in the relative mRNA expression in the treatment group. ${ }^{*} \mathrm{P}<0.05$.

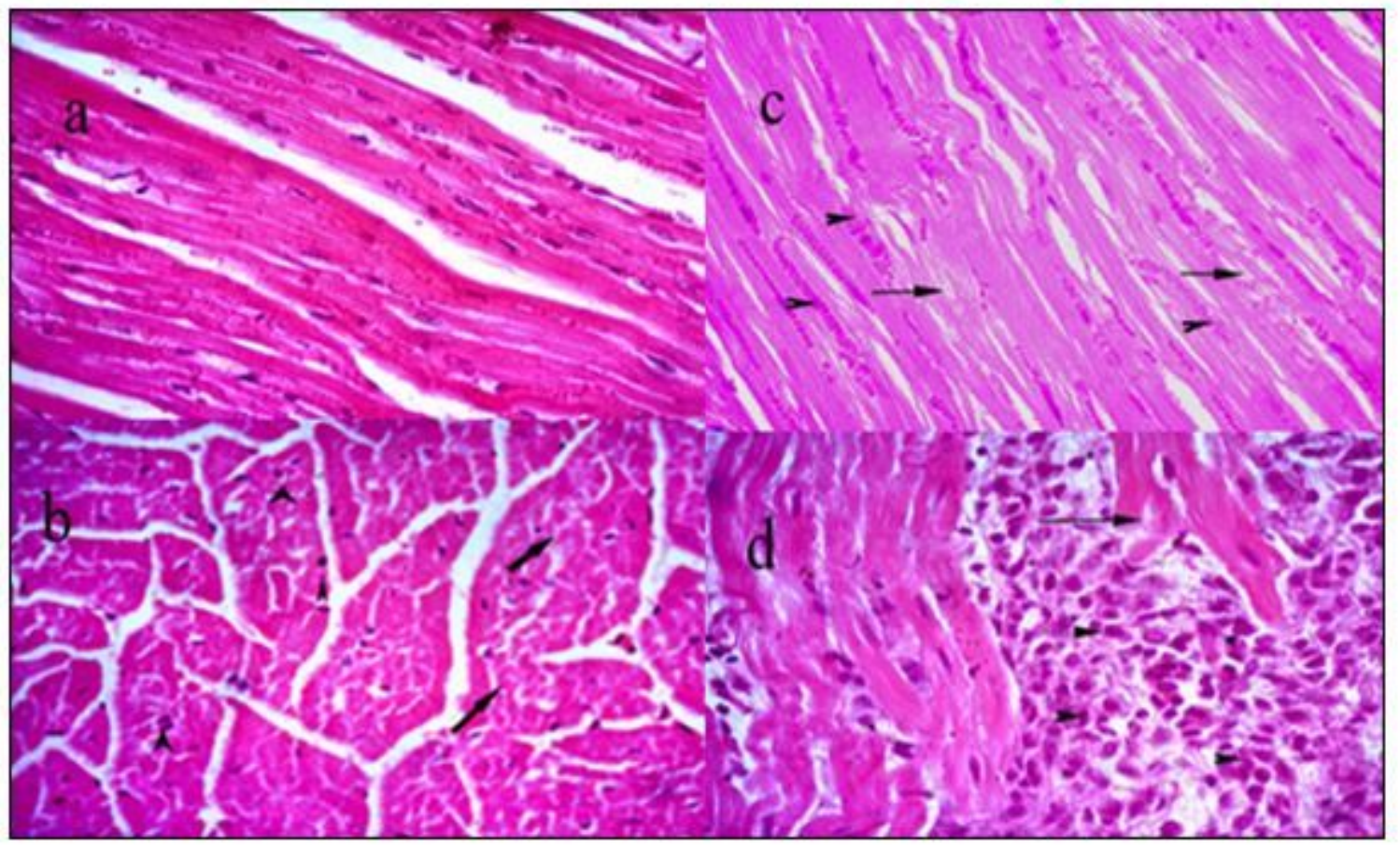

Figure 3 
H\&E staining of histopathological examination of the cardiac tissues from the control group that showed the normal cardiac structure (a), and cardiac tissue changes in the copper deficiency group (b,c,d). b, focal extensive necrosis of cardiac muscles in Cu-D group which was replaced by leukocytic infiltrations (arrowhead) and degeneration of adjacent muscles (arrows, X 200); c, focal necrosis of cardiac muscles (arrowhead) and congestion of intermuscular tissue (arrow); $d$, higher magnification of focal extensive necrosis and leukocytic infiltrations (arrowhead) and degeneration of adjacent muscle fibers (arrows, $X$ 400). 